\title{
Mutual Funds: An Outrageous Progression in Investment
}

\author{
V.B. Karuna Moorthy ${ }^{a}$, and Dr. N. Rajendhiran ${ }^{b}$ \\ Ph.D Part Time Research Scholar, Department of Management Studies, Periyar \\ University, Salem \\ ${ }^{\text {b}}$ Rtd. Professor and Director, Department of Management Studies, Periyar \\ University, Salem.
}

Article History: Received: 11 January 2021; Accepted: 27 February 2021; Published online: 5 April 2021

\begin{abstract}
Mutual funds are the key factor for the financial arbitrator. Corporations, governments, and individual investors are benefitted out of mutual funds on a large scale. Mutual funds seem to be an attractive scheme of investment among society. The new money flow in terms of investment yields enhanced results in mutual fund investment. Mutual funds attract small investors to benefit greatly due to diversified capabilities. Shareholders are benefited through mutual funds in numerous ways. This paper tries to analyse the importance of mutual funds and their need in this current scenario. Further, this paper also tries to investigate the ways in improving the growth of mutual fund investment plans among the public.
\end{abstract}

Keywords: Awareness, commitment, investment, benefits,

\section{Introduction}

Investors invest their money in mutual funds because of the return one gets back from it. An investor is a person who looks for criteria that give systematic maximization of one's personal return before investing in any mutual funds. Through mutual fund schemes, people all over the world are given wider opportunities for a large scale of investment in a stock market. Any individual may prefer mutual find because of various reasons namely convenience, cost, risk reduction, etc.

\section{Objectives}

To comprehend the attitude of the investors in general

To acquire knowledge on the investment scheme

To know about the importance of investment and its need

To impart the knowledge on investment and its necessity

Some mutual funds also provide liquidity with the intention of repurchase from the investors. An investor is a person who invests money into various entities with the aim of financial return. K. Alamelu (2017. P. 1171) puts forth her opinion on investment in her research article as,

Investment is a commitment of funds in real assets or financial assets. Investment involves risk and gain. In the present dynamic global environment, exploring investment avenues are of great relevance. Investment skills developed over a period of time are considerably influenced by experience and spadework carried out to arrive at conclusions. The success of an investment activity depends on the knowledge and ability of investors to invest, the right amount, in the right type of investment, at the right time.

\section{The different types of investment include:}

Stocks,

bonds,

mutual funds,

exchange trade fund,

index funds,

certificate of deposit

High-yield savings account generally provides a good return for the investors.

The types of mutual funds are:

Equity funds

Fixed income funds

Money market funds

Three types of investors.

Pre-investor

Passive investor,

Active investor

On the whole, all that the investor needs is the return on the investment. By investing the money into the business with growing competency, one can make money easily out of the investment. An investor, by investing the share in the company, plays an active role in the operation of the daily routine of the company. The potential impact of the companies isanalysed in terms of economic status. A silent or passive investor, though one 
contributes financially, prefers not to involve in the routine operations of the firm. Silent partner has the right in involving in the company's financial statement. The greatest benefit of being a silent partner is the redemption from tax. Because the silent partners are no more considered as regular employees of the company.

\section{Benefits of mutual fund investment include:}

Easy understanding

Simple assessment

Investment is possible with a smaller amount

Less burden

Monthly investment options

In order to meet their own goals of life, people show greater interest in mutual fund investment these days. V. Sridevi (2019, p. 83) states her opinion on mutual fund investment in one of her article is worth refereeing here,

A Mutual Fund is an investment medium that pools funds from various investors and invests the funds in stocks, bonds, short-term money-market instruments, other securities or assets or some combination of these investments. The primary goal behind investment in mutual fund is to earn goods return with comparatively low risk.

Savings play an important part in human life. In the olden days, people were not aware of savings, they had spent most of their earnings for their survival. But, in later days, people have started to think about their future. They have implemented numerous investment plans based on their income. The concept of saving crept so intensely in the minds of this generation. Awareness of mutual funds has increased tremendously among the people of this current era. It is evident from the increased rate of saving in recent years. Further, the investment from people of the nation in different avenues helps in the development of the nation directly in various means.On the whole, it is found that men invest in mutual funds on a large scale. The awareness has to be brought among the female community

When investors continuously look for various opportunities in maximizing their profits, advertisements with disclaimers stating no guarantee for future performance may seem to lessen their intention in adopting the scheme of investment. When one looks at the advertisement of any mutual funds, it seems to project its victory and maximize its glory when regards to their past performance. In such a case the best possible way can be adopted before investing by an investor. They can acquire knowledge on mutual funds based on the publically available information regarding various parameters in connection to mutual fund investment.

In addition, the Government of India should also create awareness among the people to restore the faith of investors in mutual fund schemes. Further, the government should take the necessary steps in implementing various measures in disseminating the required information to the public. The government should publicize information on tax issues, frequency of payment, distribution of income, valuation procedure, and so on so that it may give awareness to the investors regarding mutual funds in specific. Transparency in disseminating all the relevant information will tremendously enhance the growth of mutual funds in the years to come.

\section{Conclusion}

When compared to the previous years, the Indian financial system has been experiencing tremendous changes in this recent years. Savings in various forms promote this healthy environment. If the market of mutual funds strives to maintain its standard in the year to come, definitely it may result in a greater benefit in the capital market of India on a larger scale. Thus it is growing outrageously in this modern world at a good pace. The financial knowledge and awareness among the people towards investment and its benefits will aid for the betterment of the nation as well as individuals.

\section{References}

1. Agarwal, G.D. (1992), Mutual funds and investors interest. Chartered Secretary, Vol. 22, Iss. 1, pp. 23-24.

2. Bindal, Meenakshi, Bhuwan Gupta and Sweety Dubey. (2019), A Study on Investors Perception towards Mutual Fund Investments (With Special Reference to Alwar City), International Journal of Engineering and Management Research, Vol. 9, Iss. 1, pp. 204-209.

3. Bollen, N. P. B., \&Busse, J. A. (2004). Short-term persistence in mutual fund performance. The Review of Financial Studies, Vol. 18, Iss. 2, pp. 569-597.

4. K. Alamelu, and G.Indhumathi, (2017), Investors Perception Towards Mutual Funds In Madurai District, Tamil Nadu, International Journal of Engineering Development and Research, Vol. 5 , Iss. 3, pp. 1171-1175.

5. Kaur, Jasvirand Nittan Arora. (2018), A Study on Investor's Perception towards Mutual Funds as an Investment Option, International Journal of Latest Engineering and Management Research (IJLEMR), PP. 107-111

6. Mishra, JanakiballavSomabhusana. (2019), A Study on Investor's Perception Towards Mutual Fund In The City of Bhubaneswar, International Journal of Economics and Management Studies (SSRGIJEMS), Vol. 6, Iss. 10, Pp. 61-68.

7. R. Ganapathi. (2015), Investors' Perception Towards Mutual Fund: An Empirical Study With Reference To Coimbatore City, Journal of Management Research and Analysis, Vol. 2, Iss. 1, Pp. 1 23. 
8. V. Sridevi. (2019), Investor's Behavior Towards Mutual Fund Investments, EPRA International Journal of Research and Development (IJRD), Vol. 4, Iss. 7, Pp. 83-88. 